\title{
ON A COLLECTION OF LAND-SHELLS FROM SOUTH CELEBES.
}

\author{
By Edgar A. Smmth, F.Z.S., etc.
}

Read 10th April, 1896.

PLATE VII.

THE specimens about to be enumerated and described were collected by Mr. A. Everett at the southern extremity of the island of Celebes, at an elevation of 2,000 feet, also at a still greater height, 4,000 to 5,000 feet, upon Bonthain Peak. Several of the species are of considerable interest, notably the Bulimoid form, which appears to approximate more closely to the genus Calycia of New Guinea than to any other group. Xesta dimidiata, Hemiplecta Bonthainensis, Chloritis Howesii, and Cyclotus pyrostoma, are all very handsome forms; and the discovery of four additional species of Clausilia is of importance, as only a single species has been previously recorded. The Rev. A. H. Cooke ${ }^{1}$ in discussing the fauna of Celebes, has referred to the paucity of the species of that genus, and of Amphidromus, and to the relative proportion of Naninidæ to Helicidæ, as marking "the beginning of a distinct decrease in the Indo-Malay element." Many of these and similar deductions are often made upon insufficient knowledge of the respective faunas. In the present case, for example, the incompleteness of the list of the species of terrestrial molluses which actually occur in the island is demonstrated by the fact that, in one very limited area, $\mathrm{Mr}$. Everett has discovered no less than fourteen new forms, numerically equal to one-fourth of the previously known fauna. The greater part of the island has yet to be explored, and doubtless very many additional species will eventually be discovered. As our knowledge of this fauna is at present so incomplete, it is of very little use to compare it with that of other adjacent islands.

It is, however, interesting to note that the Philippine Obba marginata (var. sororcula), hitherto recorded only from North Celebes, also occurs in the south. Mention should also be made of the occurrence of six species of Amphidromus (eight if, like Prof. E. von Martens, we consider $A$. interruptus and $A$. Sultanus distinct from $A$. perversus), a number exceeding those known from Sumatra.

The following are the principal papers which treat upon the landshells of Celebes :-

1. E. von Martens, Malak. Blätt. 1872, vol. xx, pp. 155-177.

2. Id., Preuss. Exped. Ost-Asien, Zool. vol. ii, p. 99, etc.

3. Id., in Max Weber's Zool. Ergeb., vol. ii, p. 209, ete.

4. Id., Sitzungsb. Gesell. nat. Fr. Berlin, 1886, pp. 112-114.

5. Tapparone-Canefri, Ann. Mus. Genova, 1884, vol. xx, pp. 169-175.

1 “Cambridge Natural History," vol. iii, p. 310. 


\section{A. Species Collected by Mr. Everett.}

\section{Helicarion Wallacei. Pl. VII, Figs. 7-9.}

Testa tenuissima, pallide virescens, vitrea, polita, globosa, supra depressa, infra minutissime perforata; spira ad apicem vix elata; anfractus 3, supra convexiusculi, infra suturam concave marginati, et lineis incrementi hic illic subplicatis striati, ultimus inflatus; apertura inverse late auriformis ; peristoma marginibus conniventibus, callo tenuissimo junctis, columellari ad insertionem anguste reflexo. Diam. maj. 9 , min. $7 \cdot 5$, alt. $6 \mathrm{~mm}$.

Hab.-South Celebes, at 2,000 feet.

An excessively thin, fragile species, with an obtuse spire and large apical whorls.

\section{Helicarion Celebensis, Pfeiffer.}

Hab.-South Celebes, at 2,000 feet (Everett).

A single specimen only, younger and smaller than the type, agreeing precisely in form, but without the pale line at the suture and not whitish at the base. Notwithstanding these differences, due possibly to disparity in age, I have no doubt respecting the identification of the specimen in question.

\section{Macrochlamys indifferens. Pl. VII, Figs. 10-12.}

Testa orbicularis, angustissime perforata, fusco-cornea, polita, striis incrementi levibus sculpti; spira depresse conica; anfractus 5, lente accrescentes, leviter convexiusculi, anguste marginati; apertura oblique lunata; peristoma tenue, margine columellari ad insertionem pallido, incrassato, sed vix reflexo. Diam. maj. 8, min. 7, alt. $4 \mathrm{~mm}$.

Hab. - South Celebes, at 2,000 feet.

This species presents no special distinguishing features. The generic position of this and other similar forms is difficult to determine on the shell characters only.

\section{Microcystina consimilis. Pl. VII, Figs. 13-15.}

Testa depresse globosa, perforata, tenuis, pellucida, cornea, nitida, lineis incrementi prope suturam subplicatis striata; anfractus $4-5$, celeriter crescentes, convexiusculi, superne concave marginati, ultimus circa umbilicum interdum pallidus; apertura oblique lunata; peristoma tenue, margine columellari albo, incrassato, supra umbilicum sinuatim reflexo. Diam. maj. 11, min. 9, alt. $8 \mathrm{~mm}$.

Hab. - South Celebes, at 2,000 feet.

Very like Helicarion Celebensis, Pfr., but differing in the character of the columellar lip, etc. The margination of the whorls beneath the suture is palish in some specimens.

\section{Microcystina consons. Pl. VII, Figs. 16-18.}

Testa depresse globosa, tenuis, pellucida, fusco-cornea, lævigata, lineis incrementi substriata, anguste umbilicata; anfractus $4 \frac{1}{2}$, sublente 
accrescentes, convexiusculi, anguste marginati; apertura oblique lunata; peristoma tenue, margine columellari ad insertionem sinuatim reflexo. Diam. maj. 7 , min. 6, alt. $5 \mathrm{~mm}$.

Hab.- South Celebes, at 2,000 feet.

Smaller than $M$. consimitis, of a somewhat browner tint, with a slightly more elevated spire, and smaller body-whorl.

\section{Xesta trochus (Müller).}

Hab.-South Celebes, at 2,000 feet.

The specimens from this locality belong to the form named by Reeve Helix sulphurea. The shell he figured is peculiar in having no brown zone upon the base of the body-whorl, a feature occurring in all the specimens in the present collection. On the other hand, in the latter, the sutural band is only faintly continued upon the last whorl, and in some it is entirely wanting. The largest specimen has a diameter of $31 \mathrm{~mm}$.

\section{Xesta pimidiata. Pl. VII, Fig. 19.}

Testa orbicularis, perforata, solida, supra virens, haud nitens, infra lacteo-alba, zona obscura nigrescente cincta, circa umbilicum nigrofusco tincta, hic illic irregulariter nigro-punctata; anfractus 5-6, convexiusculi, sutura alba nigro-marginata sejuncti, apicales læves, nigrescentes, ultimus et penult. striis spiralibus confertis microscopicis sculpti, lineis incrementi obliquis tenuibus striati, ultimus ad peripheriam rotundatus, infra concentrice plus minus minute striatus, haud descendens; apertura obliqua, late lunata, alba, zona lata nigro-fusca infra medium haud ad marginem attingente picta; peristoma tenue, simplex, margine columellari prope insertionem, leviter incrassato, reflexo, et subcontorto. Diam. maj. 33, min. 27, alt. $20 \mathrm{~mm}$; apertura $11 \mathrm{~mm}$. alta, 16 lata.

Hab.-South Celebes, 2,000-5,000 feet.

Four specimens of this beautiful species were collected by $\mathrm{Mr}$. Everett. Three are coloured as described above; but the fourth has all the upper part of the spire black, excepting a white line at the suture, the body-whorl, however, becoming normally greenish.

\section{Xesta Wallacei (Pfeiffer).}

Hab.-South Celebes, at 2,000 feet.

Three varieties of this species were collected by $\mathrm{Mr}$. Everett in South Celebes, at an elevation of 2,000 feet, namely-(1) the typical form as figured in the Conchylien-Cabinet (Helix), pl. clxiv, figs. 13-15; (2) like the type, but darker above, livid purplish towards the apex, and chestnut brown near the aperture, pale beneath, with a brown stain around the umbilicus; last whorl dotted with black (dots very few on the under-surface) and encircled with a dark-brown zone, sometimes bisected by a pale line; (3) like Pfeiffer's var. $\beta$, but having a white instead of a brown peripheral band. Var. bicingulata, Von Martens, was not collected by Mr. Everett. 


\section{Hemiplecta Bonthainensis. Pl. VII, Fig. 20.}

Testa depresse conoidea, ad peripheriam obtuse carinata, perforata, tenuis, saturate vel dilute purpureo-fusca, circa umbilicum virescens, ad angulum medianum plerumque flavescens; spira breviter conica, ad apicem mediocriter acuta, haud nitida; anfractus 5-6, leviter convexiusculi, lineis incrementi obliquis areuatis aliisque spiralibus numerosis granulatim decussati, ultimus infra angulum convexior, nitens, lineis concentricis versus umbilicum sensim evanidis; apertura obliqua, late lunata, intus concolor; peristoma tenue, simplex, in exemplis adultis ad marginem levissime incrassatum et luteum, marginibus distantibus, columellari ad insertionem breviter expanso et reflexo. Var. 'Testa omnino dilute flavo-virescens. Diam. maj. 34, min. 28 , alt. $22 \mathrm{~mm}$.

Hab.-Bonthain Peak, South Celebes, at 4,000 feet.

Considerable variation in form and colour is observable in the series of specimens examined, but the sculpture is similar in all. Some examples are of a very dark purplish-brown or black colour throughout, with the exception of the umbilical region. Others are of a lighter tint. Some are greenish, with a broad purplebrown zone beneath the periphery, whilst others are uniformly light yellowish-green. The spire is more elevated and the body-whorl more inflated in some specimens than in others.

\section{Rhysota rugata (Martens).}

Nanina rugata, Martens, Preuss. Exped. Ost-Asien, Zool. vol. ii, p. 229 , pl. $x$, fig. 5 .

Hab.-South Celebes, at 2,000 feet.

This species has already been quoted from the southern part of the island by Wallace and by Martens. Young shells are very sharply keeled and angulate, and the two apical whorls are peculiarly malleated, a feature also observable in more adult specimens.

\section{1. Овва marginata (Müller).}

Var. sororcula, Martens, Preuss. Exped. Ost-Asien, Zool. ii, p. 294, pl. xvii, fig. 4.

Hab.-South Celebes, at 2,000 feet.

It is interesting to find this species occurring in the south of the island as well as the north. Similar small examples also occur at the Philippine Islands.

\section{Chloritis plena (Godwin-Austen).}

Helix (Chloritis) plena, Godwin-Austen, Proc. Zool. Soc. 1891, p. 44, pl. ii, fig. 8.

Hab.-South Celebes, 2,000 feet (Everett); Labuan (G.-A.). Var. Celebensis, n.

Only a single specimen was obtained by Mr. Everett. It is rather smaller than the type from Labuan (maj. diam. $16 \mathrm{~mm}$.$) , consisting$ of half a whorl less, the peristome is faintly tinted with livid lilac, 
and the columellar margin is not quite so broadly reflexed and is rather more oblique. The supra-peripheral band or line is narrower, and bisects an indistinct pale zone. The "finely granulate" sculpture mentioned by Godwin-Austen occurs only upon the spire, the bodywhorl in both being clothed with a dull, non-pilose periostracum.

\section{Chloritis Howesir. Pl. VII, Figs. 21, 22.}

Testa depressa, orbicularis, subanguste umbilicata, tenuiuscula, saturate castaneo-fusca, zona flavescente paulo supra peripheriam utrimque linea nigro-rufa marginata, ornata, et circa umbilicum pallida vel flavescens, epidermide minute pilosa undique induta; spira plana; anfractus quatuor, convexi, celeriter crescentes, ultimus antice oblique descendens; sutura profunda, linea nigro-fusca superiore notata; apertura subhorizontalis, lilacea, zonis externis translucentibus, late lunata; peristoma lilaceum, undique expansum, marginibus leviter conniventibus, columellari latius reflexo. Var. Testa pallidior, in exemplo unico linea inferiore deficiente. Diam. maj. 33, min. 24, alt. $16 \mathrm{~mm}$; apertura intus $11 \mathrm{~mm}$. alta, 15 lata.

Hab.- South Celebes, 2,000 feet; and Bonthain Peak, 4,000 feet.

None of the specimens from the latter locality (var. Bonthainensis) have the dark rich brown colour of the type, whilst the "hairs" of the epidermis are a trifle coarser, conspicuously fewer and further apart. The spire also has the apex elevated slightly above the bodywhorl, whereas in the specimens from the lower altitude it is depressed. This handsome species has somewhat of the form of Chloritis tuba (Albers), but is smaller, differently banded, etc. I have much pleasure in naming this beautiful shell after our distinguished President, Prof. G. B. Howes.

\section{AMremidromus perversus (Linn.).}

Hab.-South Celebes, at 2,000 feet.

Both the typical form of this species (Conchyl.-Cab., ed. 2, Bulimus, pl. ix, figs. 1, 2) and the variety interrupta (Delessert, Recueil de Coq., pl. xxvii, figs. $7 a, 7 b$ ) were collected at the above locality. This discovery of the typical form fills up a gap in the distribution, as there has hitherto been some doubt respecting the exact locality. (Vide Fulton, Ann. Mag. Nat. Hist. 1896, vol. xvii, p. 67.)

\section{Calycia Everetti. Pl. VII, Fig. 23.}

Testa ovato-conica, ad peripheriam angulata, anguste perforata, albo-pellucida, epidermide virente nitente amicta; spira conica, ad apicem papillosa; anfractus $5 \frac{1}{2}$, celeriter accrescentes, apicales $2-3$ convexi, cæteri planiusculi, infra suturam linea lactea angusta marginati, oblique striati et lineis impressis spiralibus obsoletis sculpti, ultimus amplus, in medio obtuse angulatus, malleatus vel corrugatus, et oblique striatus; apertura inverse auriformis, concolor, longit. totius $\frac{2}{3}$ fere æquans; peristoma album, haud incrassatum, leviter expansum, margine columellari supra perforationem anguste reflexo. Longit. 26 , diam. $20 \mathrm{~mm}$; apertura $16 \mathrm{~mm}$. longa, 11.5 lata. Hab.-Bonthain Peak, South Celebes, at 4,000 feet. 
This species is very peculiar, and does not suggest a comparison with any other known form. It hardly agrees with the genus Calycia in the expanded character of the peristome, but it appears to approach that group more closely than any other. I have much pleasure in associating $\mathrm{Mr}$. Everett's name with this interesting discovery.

\section{Clausilia Celebensis. Pl. VII, Fig. 24.}

Testa elongata, subclavata, saturate purpureo-fusca, apicem versus propeque suturam pallida; anfractus 10, convexiusculi, oblique tenuiter striati, penultimus ultimo latior, ultimus antice paulo ascendens; apex mammillatus; apertura inverse auriformis, longit. totius $\frac{1}{4}$ paulo minor, intus livido-purpurea; peristoma albidum, leviter incrassatum, et reflexum. Lamella superior tenuis, ad marginem attingens, inferior longe intus, subcolumellaris gracilis, obliqua, l. inferiori approximata, ad marginem labri fere attingens; plica suturalis unica elongata, supra aperturam, suturæ parallela; lunella distincta, supra aperturam sita. Longit. 24, diam. fere $6 \mathrm{~mm}$. Var. Testa tenuis pallido-cornea.

Hab.-Bonthain Peak, South Celebes, at 5,000 to 6,000 feet; also South Celebes at 2,000 feet.

Most of the specimens are of a dark purplish-brown colour, paler towards the apex and at the suture. In some of the older shells the surface becomes more or less decomposed and assumes a greenish chalky appearance, and frequently is somewhat worn away at the suture, which consequently presents a slightly channelled aspect. Only two specimens of the pale corneous variety were obtained. Some examples are much more slender than others, as shown by the following measurements: length $23 \cdot 75$, diameter $6 \mathrm{~mm}$.; length $23 \cdot 25$, diameter $5 \mathrm{~mm}$.

\section{Cladsilia simillima. Pl. VII, Fig. 25.}

Testa elongata, superne attenuata, saturate purpureo-fusca, oblique rugose striata, ad suturam denticulata; anfractus 10-11, leviter convexiusculi; apertura piriformis, intus sordide purpureo-fusca; peristoma expansum, reflexum, ad marginem pallidum; lamella superior tenuis, marginem attingens, inferior intus sæpe bifurcata, parte superiore lamellæ superiori adjuncta; lamella subcolumellaris nulla. Plicæ suturales duo, superior elongata, suturæ parallela, inferior leviter obliqua, multo brevior; plica palatalis unica obliqua, supra rimam umbilicalem sita. Longit. 20.5 , diam. $4 \mathrm{~mm}$.

Hab.-South Celebes, at 2,000 feet.

This species is very like $C$. Moluccensis, Martens, as regards form, but is more coarsely striated, strongly dentate at the suture, and of a much richer brown colour. The form and armature of the mouth are very similar.

\section{Clausilia subpolita. Pl. VII, Fig. 26.}

Testa parva, subpellucida, fusco-cornea, nitida, lineis incrementi tenuibus obliquis striata; anfractus 10 , superiores $6-7$ convexiusculi, 
cæteri minus convexi; apertura inverse auriformis, concolor; peristoma tenue, pallidum leviter expansum; lamella superior tenuis, marginem attingens, inferior obliqua, subcolumellaris parva, tenuis, ad marginem labri vix producta; plica suturalis unica, supra aperturam visibilis, suturæ vix parallela; lunella nulla. Longit. 14, diam. $3 \mathrm{~mm}$.

Hab.-South Celebes, at 2,000 feet.

The lines of growth are a little coarser behind the lip than upon the rest of the surface. The apex has a drawn-out appearance, the subapical whorls being somewhat long.

\section{Claudilia usitata. Pl. VII, Fig. 27.}

Testa $C$. subpolite similis, sed paulo major, saturate fusca, versus apicem pallida; apertura major; lamella subcolumellaris marginem attingens; plica suturalis unica, magis ad dextram; lunella distincta, in medio angulata, superne plica suturali conjuncta. Peristoma angustum, leviter expansum, margine externo (sinistro) pallide rufescente, dextro albescente. Longit. 16, diam. $3.5 \mathrm{~mm}$.

Hab.-South Celebes, at 2,000 feet.

The slightly larger size, different colour, the presence of a lunella, and other characters, distinguish this from the preceding species.

\section{Cyclotus fasciatus, Martens.}

C. fasciatus, Martens, Preuss. Exped. Ost-Asien, Zool. ii, p. 118, pl. i, fig. 3 ; Mal. Blät. 1872, vol. xx, p. 158.

Hab.-South Celebes, at 2,000 feet (Everett); near Macassar (Martens).

\section{Cyclotus politus, Sowerby, var.}

Hab.-South Celebes, at 2,000 feet.

A comparison of the types shows that $C$. politus and $C$. Amboinensis, Pfr., are merely varieties of one and the same species; and I have a very strong belief that $C$. fulminulatus, Martens, is also conspecific. The elevation of the spire, the width of the umbilicus, and the thickness of the peristome, are variable. The specimens from South Celebes are of the same form as the var. Amboinensis, that is, are less elevated in the spire than the type shell of politus. They also generally have the peristome somewhat less thickened; but the columellar margin exhibits the internal thickening for the support of the operculum, which is present in all the forms.

\section{Cyclotus pyrostoma. Pl. VII, Figs. 1-3.}

Testa orbicularis, aperte et perspective umbilicata, solida, epidermide nigro-olivacea, plus minus detrita, induta, pallide rufescens, rufo indistincte flammulata et maculata, infra peripheriam zona lata nigroolivacea picta; spira leviter elata; anfractus 5 , convexi, celeriter accrescentes, superiores tres læves, lineis incrementi striati, ult. et penult. superne spiraliter lirati, striisque obliquis arcuatis fortiter sculpti, ultimus ad peripheriam subcarinatus, antice descendens, infra haud spiraliter striatus; apertura obliqua, saturate sanguineo-rufa; 
peristoma incrassatum, pallidum, vix expansum, marginibus callo rufo junctis, inferiore valde recedente. Diam. maj. 26, min. 20, alt. $13 \mathrm{~mm}$. Operculum testaceum, supra leviter concavum, infra in medio mucronatum, versus marginem corneum; anfractus circiter 8, ad suturam plus minus carinati, transversim striati, lentissime crescentes, ultimus ad marginem excavatus.

Hab.- -South Celebes, at 2,000 feet.

In general form this species recalls Cyclophorus Woodianus of Lea. It is well characterized by the brilliant red aperture of the shell, and the somewhat strong spiral liræ upon the upper surface of the last two whorls.

\section{Cyclotus Celebensis. Pl. VII, Figs. 4-6.}

Testa orbicularis, aperte et perspective umbilicata, olivaceo-fusca, ad peripheriam zona lutea cincta, interdum superne et infra plus minus flavo maculata; spira breviter elata; anfractus 5, convexi, lineis incrementi tenuibus striati, ultimus antice descendens; apertura obliqua, intus fuscescens; peristoma duplex, margine externo expanso et reflexo, pallido, interno lutescente, continuo. Diam. maj. 20, min. 16, alt. $9 \mathrm{~mm}$. Operculum multispirale, ad suturam insigniter acute carinatum, supra fere planum, ex laminis alternatim corneis et testaceis constitum, inferne omnino corneum, in medio mucronatum.

Hab.-South Celebes, 2,000-4,000 feet.

Two specimens are uniformly brownish, with the exception of the peripheral zone; the third exhibits a sprinkling of golden specks above and a dotting below.

\section{$B$. List of the Known Species of Land-shells of Celebes. ${ }^{1}$}

Helicarion (Otesia) flammulatus, Q. and G.

\section{, , viridis, Q. and G.}

,, Celebensis, Pfr.

, Idæ, Pfr.

Wallacei, Smith.

Xesta fulvizona, Mouss. (var.).

,, Wallacei, Pfr.

,, dimidiata, Smith.

,, vitellus, Shuttl.

, Riedeli, Martens.

,, cincta, Lea.

, trochus, Müll.

, Stuartiæ, Sow. (?).

,, nemorensis, Müll. (?).

,' Sibylla, Tap.-Can.

Hemiplecta semisculpta, Martens.

, ribbei, Bttgr.

1 Species from the small island of Saleyer (Selayar, or Salayar), south of Celebes, are not included in this list. 
Hemiplecta Bonthainensis, Smith.

Rhysota rugata, Martens.

Celebensis, Pfr. ${ }^{1}$

,, limbifera, Martens.

Macrochlamys fulvocornea, Martens. indifferens, Smith.

Microcystina consors, Smith. ,, consimilis, Smith.

Trochomorpha planorbis, Lesson.

, Gorontalensis, Martens.

,, ternatana (Guill.) (Böttger).

Ganesella leucophlœa, Martens.

Eulota similaris, Férus. ${ }^{2}$

,$\quad$ suffodiens, Böttger.

, (Plectotropis) Winteriana, Pfr. (Böttger).

Planispira flavidula, Martens.

, (Trachia) pilisparsa, Martens.

Chloritis zodiacus, Férus.

,$\quad$ tuba, Albers.

,, bulbulus, Mouss.

, biomphala, Pfr.

", Lansbergiana, Dohrn. ${ }^{3}$

", Howesii, Smith.

, plana, Godwin-Austen.

Obba Listeri, Gray.

„, marginata, Müll. (var.).

, papilla, Müll.

,, heroica, Pfr.

Papuina euchroes, Pfr.

Camæna (Pseudobba) Quoyi, Desh.

,, , mammilla, Férus.

Cochlostyla (Corasia) leucophthalma, Pfr.?

Amphidromus perversus, L. (and vars.).

, sinistralis, Reeve.

, Beccarii, Tap.-Can.

,, filozonatus, Martens (var.). ${ }^{4}$

, contrarius, Müll. (var.). ${ }^{4}$

Calycia Everetti, Smith.

Buliminus (Rhachis) zonulatus, Pfr.

Opeas gracilis, Hutton.

Clausilia Molucensis, Martens.

, Celebensis, Smith.

, usitata, Smith.

, simillima, Smith.

1 Perhaps only a variety of $H$. striata, Gray (Martens).

2 Bericht Senckenberg. nat. Gesell. 1891, p. 267.

3 Nachrichtsbl. deutsch. Mal. Gesell. 1879, p. 69; Kobelt, Conch.-Cab., p. 598, pl. clxxv, figs. 1-3.

4 Fulton, Ann. Mag. Nat. Hist. 1896, vol. xvii, p. 78. 



\section{$2 \mathrm{BHL}$ Biodiversity Heritage Library}

Smith, E. A. 1896. "ON A COLLECTION OF LAND-SHELLS FROM SOUTH

CELEBES." Proceedings of the Malacological Society of London 2, 94-103.

View This Item Online: https://www.biodiversitylibrary.org/item/52043

Permalink: https://www.biodiversitylibrary.org/partpdf/202631

\section{Holding Institution}

Smithsonian Libraries

\section{Sponsored by}

Smithsonian

\section{Copyright \& Reuse}

Copyright Status: Public domain. The BHL considers that this work is no longer under copyright protection.

This document was created from content at the Biodiversity Heritage Library, the world's largest open access digital library for biodiversity literature and archives. Visit BHL at https://www.biodiversitylibrary.org. 